\title{
Enforceability of ECtHR Judgements in Russia: Alternatives of Interaction Between Jurisdictions
}

\author{
Ivan Usenkov* and Igor Morozov \\ Volgograd State University, 400062, Universitetskiy Av., 100, Volgograd, Russia
}

\begin{abstract}
Issues of enforceability of the European Court of Human Rights judgements in Russia are considered in the article. The authors infer the priority of the model, in which judgements can be unimplemented if they are contrary to the constitutional law of the country in accordance with comparative legal analysis. However, the state is ought to make everything possible in order to enforce the decision, even interpret the Constitution, if possible. The authors conclude that issues of correlation of sovereignty and regional consensus, subsidiarity principles and supranationality, interpretation of the European Convention for the Protection of Human Rights and fundamental freedoms have not obtained a response. The European Court of Human Rights should be more thorough with the aspects of the national legal systems, but rejection of the execution of its judgements is unacceptable. Relevant provisions are to be excluded from the FCL from 21.07.1994 N 1-FCL «The Constitutional Court of the Russian Federation».
\end{abstract}

\section{Introduction}

Issues of restoration of global and regional law, legal integration of separate countries into the united international area are not new, but still relevant. Complicated relationships between Russia and the European Community caused protracted conflict between the European Court of Human Rights (hereinafter the Court, the ECHR) and Russian judiciaries. In last years, as it first seems, the controversies have been unequivocally resolved. But are the responses correct? And are there any preconditions for the further changes?

The issue has been considered both in Russia and in Europe. There is no sense in listing all the scientists, who addressed the issue, because most of the masters of the constitutional and international law did it. It should be noted that research papers devoted to the enforceability of the ECHR judgements in Russia were written by a big number of the judges of the Constitutional Court of the Russian Federation. V.D. Zorkin, K.V. Aranovskiy, S.D. Knyazyev, T.G. Morschakova, S.P. Mavring and others have written about it.

Meanwhile, tendencies of the Russian Federation issue settlement are highly controversial. The purpose of the study is analysis of new practical controversies and longitudinal theoretical research, the result of which will be the synthesis of the most polite way of relationship development between Russia and the ECHR.

\section{Study}

Russia joined the European Convention on Human Rights and Fundamental Freedoms (hereinafter the Convention, the ECHR) in 1998, recognizing the jurisdiction of the European Court of Human Rights with the regard to the interpretation and application of the Convention in cases when the Russian Federation violates the ECHR. It should be mentioned that at the moment of the ratification of the Convention not only Russia did admit relevant authorities of the ECtHR without any clauses, but also extended such authorities to the interpretation of the ECHR text by the Court. Today it acquires ever-growing importance, because here stands a question if the right applied by the ECtHR is the Convention of 1950 , or the Court has created a law different from it, which is not necessary for application by countries that had ratified the original text.

One of the most important components of the subject is the analysis of the scopes of the enforcement of the ECHR judgements in foreign countries. Both supporters and opponents of necessity of enforcement of the Court's judgements mostly express the same positions of various European Courts, but from different perspectives.

Thus, judges of the Constitutional Court of the RF K.V. Aranovskiy and S.D. Knyazyev notice that priority of the Convention over the rules of the constitutional law has been questioned by such countries as Austria, Germany, Italy, Turkey and others [1]. Let us consider how correct it is to talk about the similarity between the views on the issue of these countries' Courts and the Constitutional Court of the Russian Federation.

Austria included provisions of the Convention in its Constitution, however, there is divergence in interpretation of its provisions between the Austria's

\footnotetext{
*Corresponding author: usenivan@yandex.ru
} 
Constitutional Court and the ECtHR. The Constitutional Court of Austria observed that at the moment of the accession of Austria to the Convention, such broad interpretation was not considered, in particular, on the issue of guarantying the courts' decisions on all the questions, including administrative law. However, the Constitutional Court of Austria had subsequently changed its own interpretation in such a way it could match the interpretation of the Court, without stirring up controversy with the ECtHR [2]. That is to say, Austria escaped direct conflict.

Opponents of the enforcement of the Court's judgements, as an example, most frequently give the position of Germany. The Federal Constitutional Court of Germany set the basic law higher than ECHR in the legal provisions hierarchy, while considering the «Gergul case». The FCC of Germany observed that provisions of the Convention might be not applied if their realization will cause violation of the basic law of Germany, because its fundamental principles have a priority over international treaties. At the same time, the Federal Constitutional Court noted that the ECHR's judgements are taken into account in any case, and if violations of the basic law can be eliminated without contravention of the last one, than the ECHR's judgement is to be applied. Such position is formally similar to the position of the Russian Federation.

However, Germany continues carrying out its international duties after demonstrating such a strong position. If international standards of the ECHR were not implemented in national laws on the case of Gergul like the Court required, later the FCC of Germany established an appropriate enforcement machinery, technically fulfilling formerly ignored decision. Afterwards, the German Court's judgement, which came into conflict with the ECHR's decision, was reconsidered. Therefore, FRG may consider nonenforcement of the ECHR's decisions possible, but still feels responsible for its international responsibilities and makes everything possible to perform its functions.

The position of the Constitutional Court of Italy is pretty similar to position of the Federal Constitutional Court of Germany. In 2007, the European Court of Human Rights ruled against the state after considering the «Scordino v. Italy» case. The Court declared acts, which allowed Italy to nationalize property without buying it out, infringing standards of the Convention. The Constitutional Court of Italy considered that if there was a real contradiction between the Convention and the Constitution of the Italian Republic, than the Court ought to check the compatibility of the standards of the acts. And if there was a contradiction, the Convention standards would only be applied in the part where they did not violate the constitutional principles.

In 2012, the Constitutional Court denied the conclusions of the ECtHR on the case of «Moggio and Others v. Italy», because considered that contradiction between conventional and constitutional protection of citizens' right shall be resolved with reference to the following conditions:

- guarantees to protect the rights shall be ultimate;
- protection of fundamental rights should not interfere with the other rights and legitimate interests that are protected by the Constitution.

In this way, the Constitutional Court of the Italian Republic repeatedly insisted on the fact that the ECHR is subsidiary to the Constitution of the state. However, for example, in one of the last considered cases it admitted that standards, which are not in harmony with the Convention, as the ECtHR noticed, are really unconstitutional and should be brought into line with the ECHR in a way the Court recommended.

Relationships that are far more complicated are between the ECHR and Great Britain. Confrontation started in 1997, when the ECHR's judgement on the Boyle case, according to which Great Britain interfered with the standards of fair trial, was not enforced. For the past twenty years, Britain has formed a whole list of situations, when the Court's judgements may be fully or partly unenforced [3]. They can be conditionally divided into the following groups:

1) Non-requirement of enforcement of the ECHR's judgements is due to subjective factors. These include cases, in which the Court's position is outdated or there is reason to believe that the Court will come to the same conclusion as the British Court. Situations, in which the Court makes mistakes because of not having the full information or wrong interpretation of the human rights, are also may be included.

2) Non-requirement of enforcement of the ECHR's judgements is due to the subsidiary nature of the Convention: the British Court within the bounds of its own national direction can make the decision; Great Britain does not consider the ECHR's decisions as final and compulsory for the national judicial system. The Court's decisions are taken into account but not in case as with previously described countries. Here they cannot be contrary to the basic substantive and procedural standards, so they can be applied only in this case.

3) Non-requirement of enforcement of the ECHR's judgements is due to the specificity of the British system of law. Non-execution of the Court's judgement may be connected both with the application of the case-law, and legislative norms: the British Court can use a precedent in particular case or consider position of the legislator as crucial. Both cases justify non-execution of the ECHR's judgement.

Thus, the courts of Europe sometimes ignore the ECtHR judgments, pointing out the primacy of the national right order in the texts of their acts, most often the role of the Constitution of the country dominating the Convention. However, not a single European state has enshrined at the legislative level the mechanism for refusing to comply with the Court's decision. Ignoring the decisions of the Court is an exceptional measure and is most often concealed under the pretext of delaying the adoption of appropriate measures before the end of the national legislative reform, which may well be of an indefinite nature [4].

Such "fair play" (of course, provided that most of the ECHR judgments are executed) allows the ECHR to look at such violations through fingers, since they are clearly not enough to apply the only sanction available in 
its arsenal - the exclusion of the state from the Council of Europe. The only case of direct confrontation is the failure of the UK to require the ECHR to grant the right to vote to prisoners. In fact, this is the only situation when the Committee of Ministers of the Council of Europe recognized the fact of non-enforcement of the Court's decision and issued a warning to the state. At the same time, Great Britain can be considered an exception, as the country has clearly and repeatedly expressed its unwillingness to participate in European integration, including by withdrawing from the European Union. Therefore, it is unlikely that the sanction in the form of an exception from the Council of Europe is a deterrent to it.

In the Russian Federation, the position of the state was expressed in the judgments of the Constitutional Court No. 27-P of December 06, 2013, No. 21-P of July 14, 2015 and No. 12-P of April 19, 2016. Initially there was no mechanism for refusing to implement the decisions of the ECHR. At the same time, the Russian court, reviewing the case on which the ECHR ruled against the Russian Federation, pointing out the violation of human rights and freedoms that are protected by the Convention, could apply to the Constitutional Court of the Russian Federation with a request to verify the constitutionality of the law when applying the law or its part.

In this situation, the Constitutional Court of the Russian Federation formally was within its competence and approach, applied, for example, in Germany and Italy. If the law, in the opinion of the ECHR, did not advise the Convention, but at the same time it corresponded to the Constitution of the Russian Federation, its provisions could be applied due to the supremacy of the constitutional law on the territory of Russia.

However, after the adoption of the second of these Resolutions by the Constitutional Court, changes were made to the FCL N 1-FCL "On the Constitutional Court of the Russian Federation" from "21" July 1994. In accordance with them, the Constitutional Court was empowered, at the request of the relevant executive body, to consider the possibility of enforcing the ECHR decision. That is, the Russian Federation has put in place a mechanism through which it can refuse to implement decisions not only of a general, but also of an individual nature.

The conflict between the states and the supranational judicial body could be explained by political reasons (especially as, as we have determined, the two most "problematic" countries are least integrated into the common European space). However, in our opinion, the key contradictions are at a deeper level.

One of the main problems is the correlation of state sovereignty and pan-European consensus [5]. The supremacy of the state on its own territory is a guarantee of its independence in domestic and foreign policy. The legitimacy of the authorities confirms the freedom to choose the means for implementation of the commitments, including commitments to provide the rights and freedoms of the individual and citizen. In addition, the ECHR itself recognizes that national governments are more familiar with the interests and characteristics of the population, the needs, the national and cultural traditions of society.

For instance, in the "Konstantin Markin v. Russia" case, the ECHR stated in its decision that the Russian law, which establishes the right of a female military to leave for child care and does not fix such a right for a male soldier, violates the provisions of the Convention on the Equality of the Sexes. Bearing in mind the traditional views of the majority of Russian citizens about military service and the role of men and women in the upbringing of the child, it is hardly possible to call the position of the Court reasonable and reasonable in relation to Russian realities. The example demonstrates that the ECHR has far less information about the mood of the population of the country than the public authorities do (the Constitutional Court of the Russian Federation has not found violations in this situation).

At the same time, we should not forget that the sovereignty of the state is limited insofar as it has committed itself to fulfill its international commitments. The position, according to which the state powers, decisions of the ECtHR in that part which does not contradict the constitutional laws of states, are quite logical. However, the reference to this rule in cases where the law, according to the ECHR, violates the Convention, but, in the opinion of the national Court, does not violate the Constitution, is an inadmissible broad interpretation of the countries. In our opinion, the basis for non-execution of the ECtHR judgments can only be a direct contradiction of its constitution.

Just as ratification of the Convention means a state's refusal from a part of its sovereignty, according to the ECHR, the fact of its entry into the Council of Europe means its integration into a single European space. The court repeatedly pointed to the existence of a "panEuropean consensus" as a tendency and commonality of changes in similar issues in most European countries. Most often, the ECtHR refers to a consensus between European countries when there is no direct normative rule in the case under consideration, however, in the member states of the Council of Europe there is a commonality of regulation of such relations.

Based on the analysis of the ECHR's practice, it is possible to draw conclusions about the progressive nature of this court instrument. Still, the Court's opinion on the existence of a pan-European consensus, on a number of issues proved premature. It should be noted that the ECHR recognized the existence of a consensus on those issues that are in fact still disputable. For example, of course, the decisions of the Court on the recognition of the right to vote for prisoners in places of deprivation of liberty are progressive and aimed at better ensuring human rights and freedoms do not at all reflect the common position of most European states. While making decision in the «Anchugov and Gladkov v. Russia» case, the ECHR did not take into account the deprivation of prisoners of active suffrage in a large part of European states, as the Constitutional Court of the Russian Federation justly stated in its decision of April 19, 2016 No. 12-P [6]. 
Thus, the lack of a balance between the sovereignty of states and the common European consensus adversely affects the relationship between the ECtHR and the Council of Europe states. On the one hand, under the guise of protecting sovereignty, the countries are looking for reasons for not fulfilling their international commitments. This is unacceptable, if only because each person should have the opportunity to apply to an external, impartial arbiter for the protection of their rights and the grounds for counting on the fulfillment of the decision of such arbitrator. Otherwise, the only mechanism for protecting the rights of a citizen persecuted by his state will be his right to insurrection. On the other hand, the ECHR has repeatedly passed decisions that are ahead of time. The desire to establish new, progressive standards of human rights is understandable, but without taking into account the peculiarities of the national order of countries and ignoring the actual lack of consensus - it is utopian.

The next crucial issue is the relation between the principles of subsidiarity and supranationality. Decisions of the ECtHR must continue the actions of states to protect the rights and freedoms guaranteed by the Convention. The court is not a continuation of the national legal system with absolute powers. This is the essence of the principle of subsidiarity of interaction between the ECtHR and the states nowadays.

However, in fact, the Court often adheres to the principle of supranationality, acting on the basis of the supremacy of the regional legal system over the right of individual states. For example, in cases of a political nature, the Court clearly enters into confrontation with states, as if elevating international law over national law. The Constitutional Court of the Russian Federation in 2016 pointed out that a departure from the principle of subsidiarity could lead to ignoring national norms in favor of rather abstract norms of the Convention.

Acknowledging the fairness of this position in general, it should be noted that the ECHR can not be understood solely within the bounds of the originally adopted document. The Convention is a "living right", which includes very concrete decisions of the ECHR [7]. The Constitutional Court of the Russian Federation does not agree with this position, as follows from the texts of its decisions. Thus, resolving the issue of the binding nature of international treaties for execution in Russia in a decree dated July 14, 2015, he pointed out that the Vienna Convention on the Law of Treaties provides that the treaty is binding if interpreted through the rules of interpretation set forth in the convention. Accordingly, if the ECHR interprets the Convention with violations found by the Constitutional Court of the Russian Federation, the Russian Federation has the right not to comply with such a decision.

Such a position, in our opinion, not only unreasonably narrows the understanding of the Convention to an abstract, frozen in the middle of the last century, and therefore an inapplicable document, but also affirms the advantage of the Constitutional Court of the Russian Federation before the ECHR in interpreting the text of the Convention. If the advantages of the national court for determining the characteristics of the public consciousness of citizens are undeniable, there is simply no reason for an advantage in interpreting the text of the ECHR.

We believe that the Court should be guided by the principle of subsidiarity, without substituting an extensive interpretation of law making. The Convention presupposes a sufficiently broad framework in order to remain relevant to our time with the help of the Court's activities. But going beyond it makes the ECHR a body with super-powers capable of creating and applying legal norms within the framework of a concrete case. At the same time, states should not, according to the principle of subsidiarity, refuse to implement the decisions of the Court, believing that he misinterpreted the provisions of the Convention. The ECHR is the only body authorized to give its mandatory interpretation and from this position, its decisions cannot be challenged.

Nevertheless, the main practical problem is, in our opinion, the possibility of refusing to comply with the ECHR's decision providing for individual measures.

1.This is a rejection of the assumed international commitment and violates the peremptory norms of international law (the position of the Constitutional Court of the Russian Federation on this issue is set out above).

2. "Impossibility of execution of the decision" as the basis for refusal to execute the decision of the European Court of Human Rights is also subjected to sharp criticism, including by the Venice Commission. In 2016 it pointed out that such a wording should be replaced with "incompatibility of the way the decision is implemented with the Constitution of the Russian Federation". The member countries of the Convention can not refuse to implement measures of an individual nature, including the payment of individual compensation, on the basis of the impossibility of execution. The Institute of the ECHR itself would otherwise have depreciated. States must find alternative ways of enforcing the decisions of the Court. So, finding in 2017 the execution of the ECHR in the Yukos case at the request of the Ministry of Justice of the Russian Federation impossible, the Constitutional Court dealt a huge blow to the reputation of the Russian judicial system.

3. There is a possibility that the Constitutional Court may be a judge in its own case, which happened in the YUKOS case. The ECHR's decision contradicted part of the decision of the Constitutional Court of the Russian Federation from July 14, 2005. When in 2017 the Constitutional Court considered the request of the Ministry of Justice, he also assessed his own actions twelve years ago. Thus, Russia in this case allowed two significant violations only in the execution of the Court's decision, not counting the essence of the violation itself, when the state considered that it could neglect the norms of legislation if the offender, in turn, violated them.

However, an even more surprising mechanism was applied to the "Yves Rocher case." In October 2017, the ECHR ruled against the Russian Federation, considering that the verdict to the Navalny brothers was unfounded and convicted with violation of the right to a fair trial. On April 25, 2018, the Presidium of the Supreme Court 
considered the merits of the case. According to the Code of Criminal Procedure, for new circumstances (which include, among other things, the decision of the ECtHR), the court "annuls or modifies judicial decisions in a criminal case in accordance with the decision of the European Court of Human Rights". According to media reports (including official ones, the decision of the Russian Federation Armed Forces was not published at the time of writing of the article), the Presidium of the Russian Federation Armed Forces left the verdict unchanged, resumed the case to consider new circumstances.

The issue of the constitutionality of the applied laws was not put to the Constitutional Court, the request for the implementation of the decision was not submitted to the competent executive authorities. Thus, even with legislative possibilities to refuse execution of the Court's judgments, in certain cases the Russian Federation prefers to ignore its decisions.

\section{Study results}

The correlation of human rights and freedoms as the supreme value and sovereignty of the state is an extremely important and urgent issue for the entire European community. In the Russian Federation, this issue is the most acute. On the one hand, Russia is not sufficiently integrated into the European space to fully rely on the authority of the decisions of the European Court of Human Rights. The Court sometimes makes decisions that are weakly correlated with Russian reality; moreover, based on the political situation, its impartiality can not be generally accepted. In this regard, the idea of priority of the Constitution of the country, the possibility of non-fulfillment of decisions that do not comply with it is rational.

On the other hand, the priority of the interpretation by the Constitutional Court of the Russian Federation of the Convention before the interpretation of the ECtHR, its authority to verify the fulfillment of the ECtHR decision, the opportunity to appear as a judge in its own case, the factual disregard of the Court's judgments by the Russian Federation are inadmissible in a democratic state. This can not but lead to abuse by the authorities, the domination of the state over the individual.

We agree with the position of A. Von Bogdandi, who wrote about the need to replace the hierarchy of national constitutions and international acts with the weighing of constitutional values [8]. The US Supreme Court pointed out that national legislation should never be interpreted in such a way as to violate international norms if at least some possible construction remains $[9,10]$. Of course, the ECHR should be more attentive to the peculiarities of national legal systems, but the Russian Federation should also seek ways to enforce the decisions of the Court, rather than bypassing them. Interpretation of constitutional norms in favor of the fulfillment of international obligations, if such an interpretation is possible, and non-fulfillment of the Court's decisions only in exceptional cases is an obvious solution to the problem. It should, however, be taken into account that it is possible only if the participants of these relations are conscientious and benevolent.

\section{Conclusions}

Taking into account the foregoing, we consider the possibility of refusing to comply with the ECtHR judgments with regard to measures of an individual character inadmissible, the relevant provisions being subject to exclusion from the FCL of July 1, 1994 No. 1FCL "On the Constitutional Court of the Russian Federation". Cases of ignoring the decisions of the ECtHR, contrary to accepted international commitments, without observing the legislatively established procedures for refusing to execute, discredit the Russian judicial system. It remains to wait for the decision of the Committee of Ministers of the Council of Europe and express the hope that it will be an impetus for the development of relations between Russia and the ECHR in a new direction, and not for their final break.

\section{References}

1. K.V. Aranovsky, S.D. Knyazev, Enforcement 1, 139-150 (2017)

2. H. Haller, Material of Conference on the Interaction of National Courts with European Courts (Strasbourg, 2007)

3. D.B. Arden, Yearbook of European Law 29(1), 27 (2010).

4. D. Gomien, D. Harris, L. Zvaak, Law and Practice of the European Convention on Human Rights and European Social Charter (Council of Europe, Strasbourg, 480, 1998)

5. K. Dzehtsiarou, German Law Journal German Law Journal 12, 1730-1745 (2011)

6. K.M. Khudoley, Bulletin of Perm University. Juridical sciences 38, 463-473 (2017)

7. I.V. Kalinsky, V.I. Chervonyuk, Bulletin of Economic Security 3, 26-33 (2017)

8. A. Bogdandy, International Journal of Constitutional Law 3-4, 397-413 (2008)

9. G. Betlem, Oxford Journal of Legal Studies 3, 397418 (2002)

10. K. Hesse, Grundzuge des Verfassungsrechts der Bundesrepublik Deutschland (Heidelberg, 1999, 335) 